Creative commons User License: CC BY-NC-ND

Abstracted by: EBSCOhost, Electronic Journals Service (EJS),

Google Scholar, Directory of Open Access Journals (DOAJ),

Journal Seek, Scientific Commons,

Food and Agricultural Organization (FAO), CABI and Scopus
Journal of Agricultural Extension

Vol. XX (X) XXXXXX, 20XX

ISSN(e): 24086851; ISSN(Print); 1119944X

http://journal.aesonnigeria.org

http://www.ajol.info/index.php/jae

Email: editorinchief@aesonnigeria.org

\title{
Climate Change Mitigation and Adaptation Strategies Used by Farmers in Imo State, Nigeria \\ http://dx.doi.org/10.4314/jae.v20i2.10
}

\section{Okoroh J. P.}

Department of Agricultural Economic and Extension, Imo State University, Owerri, Imo state Nigeria okorohjuochi@yahoo.com.08066395506

Olaolu Michael. 0 .

Department of Agricultural Extension, University of Nigeria, Nsukka, Enugu state, Nigeria. michealolaolu@yahoo.com.08065489702

\section{Igbokwe Edwin. M.}

Department of Agricultural Extension, University of Nigeria, Nsukka, Enugu state, Nigeria.emigbo@yahoo.com.08034261915

\section{Abstract}

This study examined the strategies employed by farmers to mitigate the effects of climate change on agricultural practices. A structured interview schedule was used to collect data from 220 farmers. Frequency, percentages and mean statistic were used to present the results of the data collected. The results show that the mean age of the farmers was 51 years with an average of 22 years of farming experience. The majority (75\%) of the farmers were aware of climate change within their environment. Self-observation and experience (42.4\%) over the years was the source of awareness of climate change. The majority (73.6\%) of the farmers opined that in recent times, flooding had increased which is an indication of climate change. Reduction in the use of generator to get power in the farmers' houses (69.1\%) and crop rotation practices $(67.3 \%)$ were mitigation and adaptation strategies employed by the farmers against the effect of climate change. The study recommends that government of states should enforce the policy on afforestation as a mitigation measure against climate change.

Keywords: Mitigation strategies, Climate change adaptation, Agricultural practices.

\section{Introduction}

Climate change has become a global issue in recent times manifesting in variations of different climate parameters including cloud cover, precipitation, temperature ranges, sea levels and vapour pressure (Ministry of Environment of the Federal Republic of Nigeria (MoEFRN) 2003). The variations in climate parameters affect different sectors of the economy such as agriculture, health, water resources, energy etc. The main cause of climate change has been attributed to anthropogenic 
Creative commons User License: CC BY-NC-ND

Abstracted by: EBSCOhost, Electronic Journals Service (EJS),

Google Scholar, Directory of Open Access Journals (DOAJ),

Journal Seek, Scientific Commons,

Food and Agricultural Organization (FAO), CABI and Scopus
Journal of Agricultural Extension

Vol. XX (X) XXXXXX, 20XX

ISSN(e): 24086851; ISSN(Print); 1119944X

http://journal.aesonnigeria.org

http://www.ajol.info/index.php/jae

Email: editorinchief@aesonnigeria.org

(human) activities. For example, the increased industrialization in the developed nations has led to the introduction of large quantities of greenhouse gases (GHGs), including carbon (IV) oxide (CO2), methane $(\mathrm{CH} 4)$ and nitrous oxide (N2O) into the atmosphere.

Climate change refers to any change in climate over time, whether due to natural variability or as a result of human activity (Nnaji, 2012). It refers to a change in climate which is attributed directly or indirectly to human activities, that alters the composition of the global atmosphere and which is in addition to natural variability observed over comparable time periods (Intergovernmental Panel on Climate Change (IPCC), 2007).

There are two responses to global climate change namely mitigation and adaptation. Mitigation refers to intervention or policies to reduce the emissions or enhance the absorption of greenhouse gases while adaptation refers to responses to the changing climate and policies to minimize the predicted impacts of climate change (Sari Kovats, nd in Women and Children Development Initiative (WACDI), 2011). Because of the speed at which change is happening due to global temperature rise, it is urgent that the vulnerability of developing countries to climate change impacts is reduced while their capacity to adapt is increased and national adaptation plans are implemented (UNFCCC, 2007 in WACDI, 2011). Adaptation options for ecosystems include control of deforestation, improved rangeland management, expansion of protected areas and sustainable management of forests (IPCC, 1997 in WACDI, 2011). Adaptation options for hydrology and water resources include water harvesting, management of water flow from dams and more efficient water usage. Adaptation measures in African coastal zones include building of sea walls and relocation of vulnerable human settlement and other socio-economic facilities. Although adaptation options, including traditional coping strategies are available, in practice, the human, infrastructural and economic response capacity to affect a timely response may well be beyond the economic means of some African countries (IPCC, 1997 in WACDI, 2011). 
Creative commons User License: CC BY-NC-ND

Abstracted by: EBSCOhost, Electronic Journals Service (EJS),

Google Scholar, Directory of Open Access Journals (DOAJ),

Journal Seek, Scientific Commons,

Food and Agricultural Organization (FAO), CABI and Scopus
Journal of Agricultural Extension

Vol. XX (X) XXXXXX, 20XX

ISSN(e): 24086851; ISSN(Print); 1119944X

http://journal.aesonnigeria.org

http://www.ajol.info/index.php/jae

Email: editorinchief@aesonnigeria.org

Climate change adaptation is increasingly becoming an area of growing interest and engagement for many developing countries that unfortunately bear the brunt of an overheating planet caused by developed countries. The uncertain effects of a changing climate on Nigeria's economy pose significant setbacks for meeting development targets like Nigeria's aspiration to be among the twenty best performing economies of the world by the year 2020 [Vision 20:20:20] and achievement of the Millennium Development Goals (Stanley, 2012).

Stanley (2012), asserted that typical of most developing countries, Nigeria's 167 million people rely heavily on their environment as well as the natural resource base for their livelihood. The fact that Africa's most populous country runs dangerously on a mono-product economy oiled by cheap hydrocarbon deposits, underscores this heavy dependence on natural resources. Climate change-induced losses and the unsustainable use of these invaluable resources appear to be a malignant problem that has elevated itself to a real development challenge in Nigeria.

In most studies, rural farmers' level of awareness seems to be on increase regarding their experiences in change and length of seasons, incidence of environmental hazards such as flood, droughts, and crop failures, long term shift in wind speed, change in rainfall intensity and uncertainty of rain etc. (Morghadiya and Smarden, 2011). These are among the common indicators of climate change well known to rural farmers the world over. However, are people also aware that most human activities contribute to climate change? Adaptation generally is primarily tailored towards agricultural productions principally through irrigation and planting crop resistant species, most local farmers are aware that the stress on their local environment and livelihoods has increased and low capacity for adaptation is a serious issue (Jones et al., 2011 in Egbe, Yaro, Okon \& Bisong, 2014). According to Pettengell (2010) in Egbe at al (2014), poverty, more than any other factor, determines vulnerability to climate change and limits adaptive capacity. It is pertinent to strengthen adaptation of poor farmers to increase their productivity. Ufuoku (2011) 
Creative commons User License: CC BY-NC-ND

Abstracted by: EBSCOhost, Electronic Journals Service (EJS),

Google Scholar, Directory of Open Access Journals (DOAJ),

Journal Seek, Scientific Commons,

Food and Agricultural Organization (FAO), CABI and Scopus
Journal of Agricultural Extension

Vol. XX (X) XXXXXX, 20XX

ISSN(e): 24086851; ISSN(Print); 1119944X

http://journal.aesonnigeria.org

http://www.ajol.info/index.php/jae

Email: editorinchief@aesonnigeria.org

in Egbe at al (2014), corroborate this fact adaptation to climate change requires farmers to realize that the climate has changed and they must be assisted to identify useful adaptation strategies and implement them.

The rural farmers, whose livelihoods depend on the use of natural resources, are likely to bear the brunt of adverse impacts of climate change. This makes the need for farmer to adapt to climate change very imperative for optimum output. Adaptation measures to climate change have to do with living with climate change, for example agroforestry, conservation agriculture, inter-cropping, biodiversity and collection of rainwater for agricultural use referred to as rainwater harvesting. Therefore the pertinent questions that arises are: what are the socioeconomic characteristics of these rural farmers? If yes what are the sources of their awareness? What is Climate change called in the local language of these rural farmers? What are the adaptation and mitigation strategies used by farmers to cushion the effects of climate change? This questions are what this study seeks to answer.

The specific objectives of this study includes to:

1. determine the socioeconomic characteristics of the farmers;

2. ascertain the awareness of the farmers of climate change;

3. identify local names these farmers call climate change; and

4. assess the adaptation and mitigation strategies farmers use cushion the effects of climate change.

\section{Methodology}

The study was carried out in Imo State which is among the five states in the Southeast geopolitical zone of Nigeria. It lies within latitude $4^{\circ} 45^{\prime} \mathrm{N}$ and $7^{\circ} 15^{\prime} \mathrm{N}$ and longitude $6^{\circ} 50^{\prime} \mathrm{E}$ and $7^{\circ} 25^{\prime} \mathrm{E}$ and covers an area of about 5100 square kilometres (www.imostate.gov.ng). Administratively, Imo State comprises of three senatorial zones namely: Okigwe, Orlu and Owerri zones. The population of the state stands at 3,927,563 and the population density varies from 230 persons per square kilometer in Oguta /Egbema areas to about 1,400 persons per square kilometer in 
Creative commons User License: CC BY-NC-ND

Abstracted by: EBSCOhost, Electronic Journals Service (EJS),

Google Scholar, Directory of Open Access Journals (DOAJ),

Journal Seek, Scientific Commons,

Food and Agricultural Organization (FAO), CABI and Scopus
Journal of Agricultural Extension

Vol. XX (X) XXXXXX, 20XX

ISSN(e): 24086851; ISSN(Print); 1119944X

http://journal.aesonnigeria.org

http://www.ajol.info/index.php/jae

Email: editorinchief@aesonnigeria.org

Mbaise, Mbano, and Mbaitoli areas (National Population commission, 2006). Rainfall distribution is bi-modal with peaks in August and September. The rainy season begins in March and lasts till October. Variation in annual rainfall is between 1990 $\mathrm{mm}-2200 \mathrm{~mm}$. Temperature is uniform in the State with mean annual temperature of about $20^{\circ} \mathrm{C}$. The annual relative humidity is $75 \%$ (www.imostate.gov.ng). The State lies within the rainforest agro ecological zone of Nigeria.

The population for the study comprised of all farmers in Imo state. A multistage sampling technique was used to sample one of the three senatorial zones being Okigwe zone, from this zone, random sampling was used to select four local government areas (LGAs) out of the six LGAs in the zone. From these LGAs, 2 autonomous communities were randomly selected making it a total of 8 communities sampled for the study. Two village communities were then sampled from each of the autonomous communities randomly and this gives a total of 16 villages sampled. From each of these villages, lists of farmers were obtained from which 15 practising farmers were sampled. This brings the total sampled farmers to 240 farmers, but 20 copies of the questionnaire used to collect data from the sampled farmers were not fund to be useable as such 220 farmers' responses was used for the study. A structured interview schedule was used to collect data. The socioeconomic characteristics of the farmers was measured by sex, marital status, age among others while awareness was measures on a Yes or No options. The farmers were masked to supply the sources of awareness as well as the local name of climate change. To identify the adaptation and mitigation strategies, farmers were asked to indicate from the list of variables their perceived strategies they use. Frequency, percentages and mean statistics were used to summarize the results of the data collected.

\section{Results and Discussion}

\section{Socio-economic characteristics of the respondents}

The result presented on Table 1 shows that the majority $(60.0 \%)$ of the respondents are female while the remaining $40 \%$ are male. The implication of these distribution of 
Creative commons User License: CC BY-NC-ND

Abstracted by: EBSCOhost, Electronic Journals Service (EJS),

Google Scholar, Directory of Open Access Journals (DOAJ),

Journal Seek, Scientific Commons,

Food and Agricultural Organization (FAO), CABI and Scopus

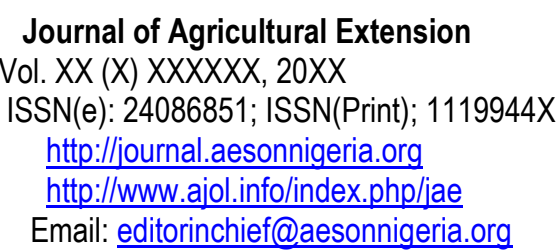

these respondents shows that the area study could have been a female dominated farming communities. The mean age of these farmers is about 51 years. The results also shows that the majority (85.9\%) of these farmers are married. The marital status shows that most of these farmers already have families they are responsible to and therefore needed more resources and food to take care of these members of the family. On their highest educational level, the results show that $23.6 \%$ of the respondents is secondary school completed This result implies that these farmers have a low levels of education probably due to the fact that they are rural dwelling people and may not have access to good schooling facilities or even be able to afford further schooling.

The average house hold size among these respondents is seven persons. This shows that theses farmers have an average size household that is their household sizes are not too large and are not really small in size. This could be as a result of the culture and believes of these people. On the years of farming experience, the average number of years in farming is 21.6 years, this is an indication that these farmers have a good years of experience in farming to qualify them to able to respond to the issues relating to climate change in their farming experience even as it relates to adaptation and mitigation strategies employed by them as well as other co farmers like them in their communities. 
Creative commons User License: CC BY-NC-ND

Abstracted by: EBSCOhost, Electronic Journals Service (EJS),

Google Scholar, Directory of Open Access Journals (DOAJ),

Journal Seek, Scientific Commons,

Food and Agricultural Organization (FAO), CABI and Scopus
Journal of Agricultural Extension

Vol. XX (X) XXXXXX, 20XX

ISSN(e): 24086851; ISSN(Print); 1119944X

http://journal.aesonnigeria.org

http://www.ajol.info/index.php/iae

Email: editorinchief@aesonnigeria.org

Table 1: Percentage distribution of respondents according to their socioeconomic characteristics

\begin{tabular}{|c|c|c|}
\hline Variable & $\begin{array}{c}\text { Percentage (n- } \\
\text { 240) }\end{array}$ & Mean (M) \\
\hline \multicolumn{3}{|l|}{ Sex } \\
\hline Male & 40.0 & \\
\hline Female & 60.0 & \\
\hline \multicolumn{3}{|l|}{ Age (years) } \\
\hline $20-29$ & 10.0 & \\
\hline $30-39$ & 15.0 & \\
\hline $40-49$ & 20.9 & 50.6 \\
\hline $50-59$ & 20.9 & \\
\hline $60-69$ & 9.6 & \\
\hline \multicolumn{3}{|l|}{70 years and above } \\
\hline \multicolumn{3}{|l|}{ Marital status } \\
\hline Single & 14.1 & \\
\hline Married & 85.9 & \\
\hline Divorced & 0.0 & \\
\hline \multicolumn{3}{|l|}{ Educational level } \\
\hline No formal Education & 17.7 & \\
\hline Primary school attempted & 5.5 & \\
\hline Primary school completed & 8.2 & \\
\hline Sec. school attempted & 12.7 & \\
\hline Sec. school completed & 23.6 & \\
\hline OND/NCE & 16.8 & \\
\hline HND/ First degree & 15.5 & \\
\hline Higher degrees (MSC/ Ph.D.) & 0.0 & \\
\hline \multicolumn{3}{|l|}{ Household size (number) } \\
\hline $1-3$ & 12.3 & \\
\hline $4-6$ & 32.2 & \\
\hline $7-9$ & 38.2 & 7 \\
\hline $10-11$ & 17.3 & \\
\hline \multicolumn{3}{|c|}{ Years of farming experience (Years) } \\
\hline $1-10$ & 29.5 & \\
\hline $11-20$ & 30.9 & \\
\hline $21-30$ & 10.9 & 21.6 \\
\hline $31-40$ & 18.6 & \\
\hline $41-50$ & 9.1 & \\
\hline 50 years and above & 0.9 & \\
\hline
\end{tabular}

\section{Awareness of climate change}

Figure 1 shows the majority (75.0\%) of these farmers are aware of climate change around them while the remaining $25 \%$ of them do not know about climate change. 
Creative commons User License: CC BY-NC-ND

Abstracted by: EBSCOhost, Electronic Journals Service (EJS),

Google Scholar, Directory of Open Access Journals (DOAJ),

Journal Seek, Scientific Commons,

Food and Agricultural Organization (FAO), CABI and Scopus
Journal of Agricultural Extension

Vol. XX (X) XXXXXX, 20XX

ISSN(e): 24086851; ISSN(Print); 1119944X

http://journal.aesonnigeria.org

http://www.ajol.info/index.php/jae

Email: editorinchief@aesonnigeria.org

On the sources of these their awareness, the respondents show in Table 2 that the greater proportion (42.4\%) of those farmers aware of climate change became aware of climate change around them from self-observations and experiences over the years. While $29.1 \%$ of them were from the radio and $24.2 \%$ of them indicated that their awareness of climate change came from their interactions with enlightened farmers. The remaining $4.2 \%$ of these farmers got their awareness of climate change from the television. The implication of this that the awareness of climate change is usually a thing of experience and observation of changes in the environments over time which also brings about adjustments made to cope with the changes.

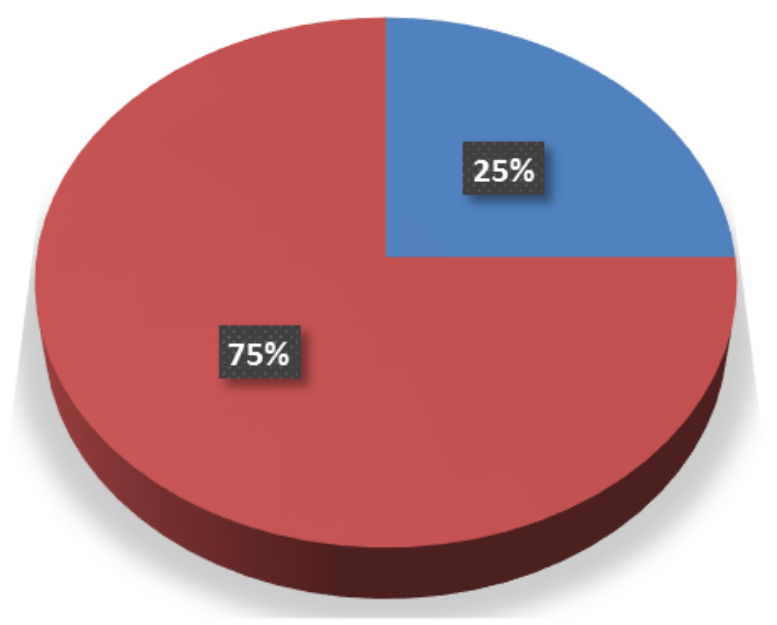

Figure 1: Percentage distribution of Farmers' on their wareness of climate change 
Creative commons User License: CC BY-NC-ND

Abstracted by: EBSCOhost, Electronic Journals Service (EJS),

Google Scholar, Directory of Open Access Journals (DOAJ),

Journal Seek, Scientific Commons,

Food and Agricultural Organization (FAO), CABI and Scopus
Journal of Agricultural Extension

Vol. XX (X) XXXXXX, 20XX

ISSN(e): 24086851; ISSN(Print); 1119944X

http://journal.aesonnigeria.org

http://www.ajol.info/index.php/jae

Email: editorinchief@aesonnigeria.org

Table 2: Percentage distribution respondents accoridng to their sources of awareness of climate change

\begin{tabular}{ll}
\hline Source of awareness & Percentage $(\mathbf{n}=\mathbf{1 6 6})$ \\
\hline $\begin{array}{l}\text { Self-observation } \\
\text { experience over the years }\end{array}$ & 42.4 \\
$\begin{array}{l}\text { Interaction with enlightened } \\
\text { farmers }\end{array}$ & 24.2 \\
Radio & 29.1 \\
Television & 4.2 \\
\hline
\end{tabular}

\section{Local names Climate change is called among these farmers}

The majority (55.8\%) of the respondents do not have any idea of what climate change is called in their local language as presented in Figure 2, the results further shows that locally, climate change is called the following: Mgbanwo ubochi (13.3\%), Mgbenwe eluigwe (12.7\%), Ntughari ubochi (12.7\%) and Mgbanwo uruku (5.5\%). This result shows that there is no definite name for climate change among these farmers and that people had different names for it. Mgbanwo ubochi meaning "changes of the days" this could imply the various changes in day length, raining seasons, dry seasons, unset of rains and harmatthan.

Mgbenwe eluigwe means "changes at the heavenly bodies". This could imply that the farmers who call climate change Mgbenwe eluigwe have observed that there has been changes in the way the heavenly bodies such as moon, sun and clouds function. Thee bodies are respondsible for the various weather. Ntughari ubochiwhich means "changes of the day" means that there are changes in the days, which were not the case many years before and as such since the primary concern of these farmers related to farming these changes could have also have been observed as it affects their faming. Mgbanwo uruku which means changes of the clouds or the climate gives the best understanding of the concept of climate change. Even though the latter gives the best description of the concept, only about $6 \%$ of the 
Creative commons User License: CC BY-NC-ND

Abstracted by: EBSCOhost, Electronic Journals Service (EJS),

Google Scholar, Directory of Open Access Journals (DOAJ),

Journal Seek, Scientific Commons,

Food and Agricultural Organization (FAO), CABI and Scopus
Journal of Agricultural Extension

Vol. XX (X) XXXXXX, 20XX

ISSN(e): 24086851; ISSN(Print); 1119944X

http://journal.aesonnigeria.org

http://www.ajol.info/index.php/jae

Email: editorinchief@aesonnigeria.org

respondents see it that way which is a reflection of their understanding of the concept of climate change. The significance of this findings is to further establish the fact that among these farmer, there are clear indication of experiences of climate change and their best means of understanding the phenomenon among these farmers.

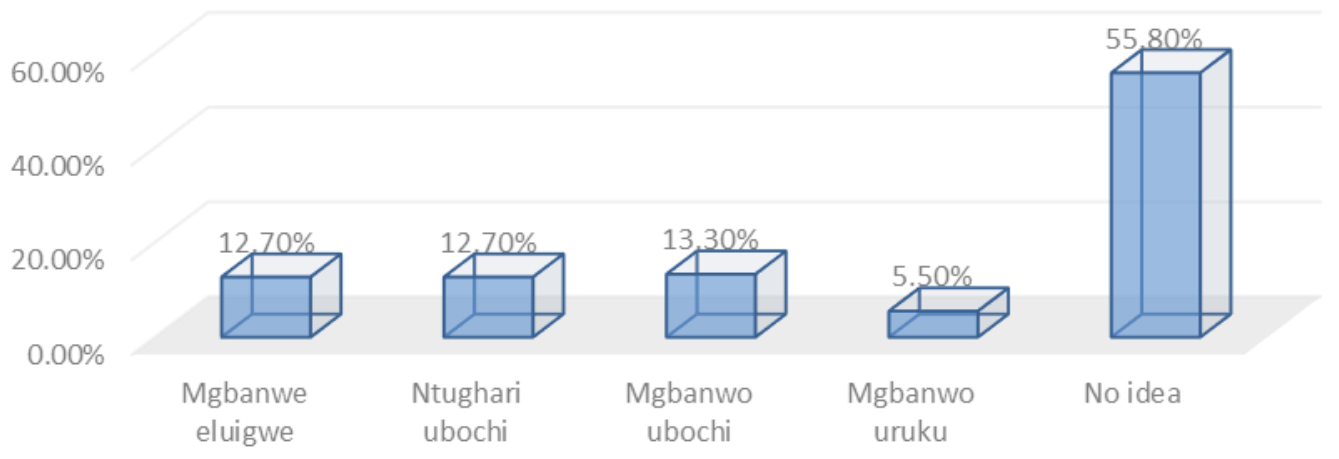

Figure 2: Percentage distribution of the names given to climate change among respondents

\section{Mitigation and adaptation strategies to cushion the effect of climate change}

Table 3 shows the various strategies indicated by these farmers as their ways of cushioning the effects of climate change. From the result presented, the strategy with the highest proportion (69.1\%) of respondents was reduction in the use of generators for electrification, this was followed by crop rotation (67.3\%), then mixed cropping practices (65.5\%) and then use water channels as draining system (63.2\%). Also following among these strategies are Mulching (60.9\%), regular weeding to avoid breed of some insects' pests (60.5\%), conservation of soil moisture through appropriate tillage operation (58.2\%) and then proper conservations of seeds (53.6\%). All these listed strategies could be said to those strategies with high adoption rates since more than half of these farmers make use of them as mean of mitigating and adapting to climate change to cushion it effects. 
Creative commons User License: CC BY-NC-ND

Abstracted by: EBSCOhost, Electronic Journals Service (EJS), Google Scholar, Directory of Open Access Journals (DOAJ), Journal Seek, Scientific Commons,

Food and Agricultural Organization (FAO), CABI and Scopus
Journal of Agricultural Extension

Vol. XX (X) XXXXXX, 20XX

ISSN(e): 24086851; ISSN(Print); 1119944X

http://journal.aesonnigeria.org

http://www.ajol.info/index.php/jae

Email: editorinchief@aesonnigeria.org

On the other hand, afforestation (6.4\%), avoidance of deforestation/tree feeling (11.8\%), planting of pest and disease resistant crops (24.5\%), breeding of drought and heat resistant crop varieties (27.7\%) and planting of cover crops (31.8\%) all had less than half of the farmers indicating their practicing of these strategies which implies a low adoption of these practices. It can be observed here that strategies that are related to more to mitigation are more among those strategies with low adoption of practice.

Generally, the results reveal that the farmers have devised various ways to reduce the effects of climate change. These strategies must have been tested by these farmers and found to be effective and as such reflect in their perception. Land management practices such as improved rotation, improved fallows and improved grazing and reduced tillage could serve as mitigation/ adaptation strategies (Guardian Environment Network, 2009).

Table 3: Percentage distribution of respondents accoridng to mitigation and adaptation strategies to cushion the effect of climate change

\begin{tabular}{lr}
\hline Adaptation strategies & Percentage \\
\hline Crop rotation & 67.3 \\
Use of water channels as draining system & 63.2 \\
Use of organic manure & 45.9 \\
Planting of cover crops & 31.8 \\
Mixed cropping practices & 65.5 \\
Planting of pest and disease resistant crops & 24.5 \\
Mulching & 60.9 \\
Regular weeding to avoid breed of some insects pest & 60.5 \\
Breeding of drought and heat resistant crop varieties & 27.7 \\
Conserving of soil moisture through appropriate & 58.2 \\
operation & \\
Mitigation strategies & \\
Afforestation & 6.4 \\
Proper conservation of seeds & 53.6 \\
Avoidance of deforestation/ tree feeling & 11.8 \\
Reduced the use of generators for electrification & 69.1 \\
\hline
\end{tabular}

\section{Conclusion and Recommendation}

The farmers from this study are well aware of the climate change and selfobservation and experience over the years was the key source of this awareness. 
Creative commons User License: CC BY-NC-ND

Abstracted by: EBSCOhost, Electronic Journals Service (EJS),

Google Scholar, Directory of Open Access Journals (DOAJ),

Journal Seek, Scientific Commons,

Food and Agricultural Organization (FAO), CABI and Scopus
Journal of Agricultural Extension

Vol. XX (X) XXXXXX, 20XX

ISSN(e): 24086851; ISSN(Print); 1119944X

http://journal.aesonnigeria.org

http://www.ajol.info/index.php/jae

Email: editorinchief@aesonnigeria.org

Though most of these farmers do not have a clear native expression of the concept but they devised strategies to cushion the effects of climate change and still be able to make a living from their farming activities despite the reality of climate change in their environment.

Therefore, the study recommends that government of states should enforce the policy on afforestation as a mitigation measure against climate change, in addition, there is need for government at all levels to engage extension agents who should teach farmers climate friendly practices that mitigate climate and enable effective adaptation.

\section{References}

Egbe, C. A., Yaro, M. A., Okon, A. E. \& Bisong, F. E. (2014). Rural peoples' perception to Climate variability/Change in Cross River State-Nigeria.

Guardian Environment Network (2009). Climate change and energy mitigation,

Wednesday April 8 a periodical publication.

Intergovernmental Panel on Climate Change (IPCC) (2007). Climate Change 2007:

Climate Change Impacts, Adaptation and Vulnerability. Available at http://www.IPCC/cly/spnibavr.pdf. 13/11/07

Ministry of Environment of the Federal Republic of Nigeria (2003). Nigeria's First

National Communication under the United Nations Framework Convention on Climate Change. Abuja, Nigeria.

Morghadiya, R., and Smarden, R. S. (2011). Farmers' Perception of Risk, Impacts

and Adaptation to Climate Change. Perspectives from Western India Dinesh:

College of Environmental Science and Forestry.

National Population Commission, (NPC) (2006). Population figure. Federal republic of Nigeria, Abuja. Retrieved from http://www.npc.gov

Nnaji, C. E. (2012). Effects of Climate Change on Household Water Sources in Benue State, Nigeria. An M.SC. Project thesis submitted in the Department of Agricultural Extension, University of Nigeria, Nsukka. 
Creative commons User License: CC BY-NC-ND

Abstracted by: EBSCOhost, Electronic Journals Service (EJS),

Google Scholar, Directory of Open Access Journals (DOAJ),

Journal Seek, Scientific Commons,

Food and Agricultural Organization (FAO), CABI and Scopus
Journal of Agricultural Extension

Vol. XX (X) XXXXXX, 20XX

ISSN(e): 24086851; ISSN(Print); 1119944X

http://journal.aesonnigeria.org

http://www.ajol.info/index.php/jae

Email: editorinchief@aesonnigeria.org

Stanley I. (2012). Nigeria and Climate Change Adaptation. International Society of Sustainability Professionals insight report May 2012.

Women and Children Development Initiative (WACDI), (2011). Gender Dimensions and Indigenous Knowledge for Adaptation to Climate Change in South East Nigeria. A Research Report. www.imostate.gov.ng 